\title{
Конфессиональная лексика в топонимах Тувы
}

\author{
Любовь С. Кара-оол \\ Тувинский государственный университет, Российская Федерация
}

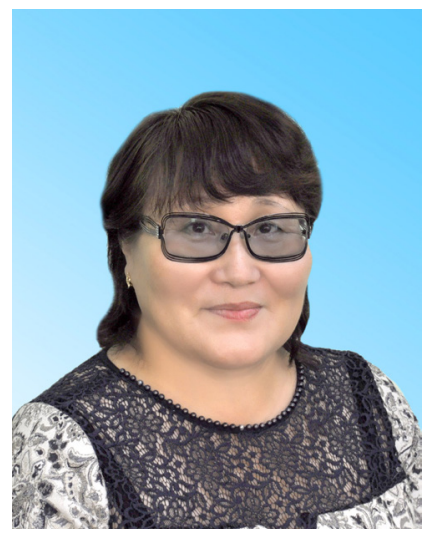

В статье анализируются топонимы Тувы, связанные с конфессиональной лексикой, которые совмещают в себе религиозно-культовые представления тувинцев и первых русских переселенцев Тувы. В качестве материалов исследования выступили данные из опубликованных работ, словарей, а также экспедиций автора по ареальным зонам (центральный, западный, юго-восточный и тоджинский диалекты) тувинского языка с 1999 nо 2020 г2.

Анализ позволил выявить следующие основные группы топонимов: а) топонимы, связанные с шаманизмом; б) топонимы, связанные с буддизмом; в) топонимы, связанные с православием.

Если тувинские топонимы, связанные с шаманизмом и буддизмом указывают на обрядовую деятельность, ритуальные атрибуты, статус служителей вероисповедания, разновидности строений, то топонимы, связанные с православием, образованы по принципу мемориальности - в память о православных святых, а также в честь религиозных праздников.

В структурном и этимологическом отношениях значительную часть топонимов на тувинском языке составляют собственно тувинские сложные слова. В качестве первого компонента сложных топонимов или простых топонимов выступают конфессиональная общетюркская лексика, лексические заимствования из монгольского, из тибетского языка посредством монгольского, а также заимствования из русского языка, а вторые компоненты сложных слов выражены общетюркскими словами. Наличие в составе топонимов с духовно-религиозным содержанием следующих формантов - гидронимических, фитонимических, оронимических - указывает на то, что они увязывались с природно-географическими особенностями Тувы.

Ключевые слова: Тува; топоним; тувинский язык; конфессиональная лексика; шаманизм; буддизм; православие; монголизм; тувинцы; русские Тувы

Работа выполнена при финансовой поддержке РФФИ в рамках научного проекта № 19-012-00073 «Трансформационные процессы в ономастике народов Центральной Азии: история и современность (на примере Тувы, Тофаларии, Калмыкии и Монголии)».

\section{Для цитирования:}

Кара-оол Л. С. Конфессиональная лексика в топонимах Тувы // Новые исследования Тувы. 2021, № 2. С. 52-66. DOI: https://www.doi.org/10.25178/nit.2021.2.5

Кара-оол Любовь Салчаковна - кандидат филологических наук, доцент кафедры теории и методики языкового образования и логопедии Тувинского государственного университета. Адрес: 667000, Россия, г. Кызыл, ул. Ленина, д. 36. Тел.: +7 (923) 549-02-64. Эл. адрес: lkaraool61@mail.ru

KARA-OOL, Lyubov Salchakovna, Candidate of Philology, Associate Professor, Chair of Theory and Methods of Language Education and Speech Therapy, Tuvan State University. Postal address: 36, Lenina St., 667000 Kyzyl, Russian Federation. Tel.: +7 (923) 549-02-64.E-mail: lkaraool61@mail.ru 


\title{
Confessional Vocabulary in the Toponyms of Tuva
}

\author{
Lyubov S. Kara-ool \\ Tuvan State University, Russian Federation
}

\begin{abstract}
The article analyzes the toponyms of Tuva associated with confessional vocabulary. They combine religious and cult beliefs of Tuvans and the first Russian settlers in Tuva. The data for the study were sourced from published works and dictionaries, as well as obtained during the author's expeditions to the areal zones (the Central, Western, South-Eastern and Todzhinsky dialects) of the Tuvan language in 1999-2020.

The analysis revealed the following main groups of toponyms: a) toponyms associated with shamanism; b) toponyms associated with Buddhism; c) toponyms associated with Orthodoxy.

If Tuvan toponyms associated with shamanism and Buddhism indicate ritual activities, ceremonial attributes, status of clergy, and types of buildings, then toponyms associated with Orthodoxy are formed according to the principle of memoriality - in memory of Orthodox saints, as well as in honor of religious holidays.

Structurally and etymologically, a significant part of toponyms in the Tuvan language are actually Tuvan compound words. The first component of complex toponyms or simple toponyms comprises common Turkic confessional vocabulary, lexical borrowings from Mongolian and from Tibetan through Mongolian, as well as borrowings from Russian. And the second components of complex words are expressed by common Turkic words. The presence of the following formants - hydronymic, phytonymic, and oronymic ones - in the composition of toponyms with spiritual and religious content indicates that they were related to the natural and geographical features of Tuva.
\end{abstract}

Keywords: Tuva; toponym; Tuvan language; confessional vocabulary; shamanism; Buddhism; Orthodoxy; Mongolism; Tuvans; Russians in Tuva

\section{Financing}

The article was written with financial support from the Russian Foundation for Basic Research within the framework of the scientific project "Transformation Processes in Onomastics of Central Asian Peoples: Past and Present (Case Studies of Tuva, Tofalaria, Kalmykia and Mongolia" (No. 19-012-00073).

\section{For citation:}

Kara-ool L. S. Konfessional'naia leksika v toponimakh Tuvy [Confessional Vocabulary in the Toponyms of Tuva]. New Research of Tuva, 2021, no. 2, pp. 52-66. (In Russ.). DOI: https://www.doi.org/10.25178/nit.2021.2.5

\section{Введение}

Топонимия Тувы считается одной из исследованных пластов лексики тувинского языка (Ондар, 2007, 2008ab; Сувандии, Кара-оол, Болармаа, 2019; Сувандии, 2013, 2018, 2019; Сувандии, Кара-оол, 2020; Сат, 1969; Татаринцев, 1973, 1977ab, 1993; Бавуу-Сюрюн, Куулар, 2005; Бавуу-Сюрюн, 2018; Кара-оол, 2018, 2019ab, 2020; Ховалыг, Даржа, 2020). Исследователями изучены лексико-семантические, структурные и лингвокультурные особенности топонимов Тувы. Активная работа по исследованию тувинских топонимов продолжается до сих пор, так как данная тема остается одной из актуальных и интересных не только для лингвистов, но и для любого, который интересуется историей и семантикой названия местностей.

Целью данной статьи является изучение топонимов Тувы с духовно-религиозным содержанием, которые обусловлены традиционными верованиями населения региона - с шаманизмом, буддизмом и православием.

Причина появления топонимов с первыми двумя религиозными содержаниями объясняется тем, что шаманизм был господствующим верованием народов Центральной Азии, в том числе тувинцев, 
а буддизм в форме ламаизма получил распространения в Туве в середине XVIII века в связи с его утверждением в Монголии (Монгуш, 1992: 10-35). А немногочисленные топонимы с православным религиозным содержанием появились в начале XX в., когда шло интенсивное переселение русских крестьян в Урянхай (Тува), в связи с установлением протектората России над Тувой.

Источниковую базу исследования по конфессиональной лексике в топонимах Тувы составили полевые материалы автора, собранные с 1999 по 2020 гг. во время диалектологических и комплексных экспедиций (при поддержке Российского фонда фундаментальных исследований) по Туве (центральный, западный, юго-восточный и тоджинский диалекты) и Монголии, где компактно проживают этнические тувинцы, а также примеры, извлеченные из «Топонимического словаря Тувы» Б. К. Ондар (Ондар, 2007), из «Списка населенных пунктов Енисейской губернии и Урянхайского края. Часть 1» $(1921)^{1}$, из «Списка поселков урянхайского края. Апрель 1918 г.»², из работ М. Б. КенинЛопсана (Кенин-Лопсан, 1987), Х. Куулар (Куулар и др., 2014) и др., а также из карты «Тува в ХІХ начале ХХ вв.» из приложения к книге В. И. Дулова (Дулов, 1956).

На основе собранного материала мы видим, что значительная часть топонимов с конфессиональной лексикой связаны с шаманизмом - ранней формой религии, основанной на общении человека с духами природы и его объектами. Данные названия условно можно разделить на следующие группы: топонимы с компонентом хам - «шаман»; топонимы, связанные с шаманскими обрядами; топонимы с названиями шаманских атрибутов. Тем не менее, мы также собрали и топонимы с буддийскими лексемами, которых сгруппировали как: топонимы с названиями буддийских строений; топонимы с духовными званиями священнослужителей; топонимы с буддийскими понятиями.

Рассмотрим каждую группу.

\section{Топонимы с компонентом хам - «иаман»}

$\boldsymbol{X a м - A д ы р ~ - ~ б у к в а л ь н о ~ « п р и т о к ~ и л и ~ р а з в и л и н а ~ ш а м а н а » : ~ р е к а ~ в ~ С у т - Х о л с к о м ~ р а и ̆ о н е ~ ( О н д а р , ~ 2 0 0 7 : ~}$ 441). Хам-Адыр [хамадыр] - собственно тувинское название: хам - 'шаман / шаманский’ (Тувинскорусский словарь, 1968: 466), адыр - 'приток’ или 'развилина' (там же: 38). История появления топонима: на притоке реки с давних времен шаманы совершали обряд суг дагыыр или суг бажы дагыыр «обряд поклонения хозяину реки» с появлением первой зелени, если заболел один из членов семьи или чтобы продлить чью-то жизнь (Куулар и др., 2014: 65).

Хам-Дыт - буквально «лиственница шамана», т. е. 'священное дерево': реки в Сут-Хольском, Пий-Хемском, Тоджинском районах; местности в Улуг-Хемском и Тандинском районах (Ондар, 2007: 441-442), летняя стоянка вблизи села Чаа-Суур Овюрского района и в 20 км от села Кара-Хаак Кызылского района (Полевые материалы автора - далее ПМА, 2017). Хам-Дыт (хамдыт) - странствующий топоним, смотри Кам-Тыт - шаманская лиственница с перепутанной кроной: река, гора, ключ в Алтае (Молчанова, 1979: 202): хам - 'шаман / шаманский' см. выше; дыт - 'лиственница' (Тувинскорусский словарь, 1968: 195). История появления топонима: у рек или на указанных местностях растут лиственницы с причудливой формой, густо переплетенными ветвями в виде гнезда. В представлении тувинцев такая лиственница имеет своего духа или хозяина, поэтому называют хам дыт - 'лиственница шамана', т. е. 'священная лиственница' (Кенин-Лопсан, 1987: 31).

Хам-Дыттыг-Ой - буквально «низина с лиственницей шамана», т. е. 'низина со священным деревом’: местность, низина в Барун-Хемчикском районе (Ондар, 2007: 442). Хам-Дыттыг-Ой (хамдытыгой) собственно тувинское название: хам - 'шаман / шаманский'; дыт - 'лиственница' (Тувинскорусский словарь, 1968: 195); ой - 'низина, лощина' (там же: 315). История появления топонима: в местности и в низине вблизи города Ак-Довурака растут лиственницы с причудливой формой, густо переплетенными ветвями в виде гнезда. Как мы указали, в представлении тувинцев такая лиственница имеет своего духа, поэтому хам дыт - ‘лиственница шамана' считают священной лиственницей.

\footnotetext{
${ }^{1}$ Списки населенных пунктов Енисейской губернии и Урянхайского края. Часть 1. Списки, итоги и алфавитный указатель. Составлены по данным Всероссийской сельско-хозяйственной и городской переписи 1917 года и по другим исследованиям 1916-1919 гг. Красноярск: Типография Енисейского Губернского Союза кооперативов, 1921. 174 с. С. 146.

${ }^{2}$ Список поселков урянхайского края. Апрель 1918 г. (Национальный архив Республики Тыва, ф. 112, оп. 1, д. 84, л. 2).
} 


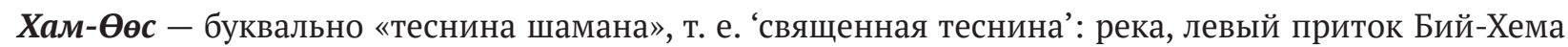
в Тоджинском районе (Ондар, 2007: 442). Хам-Өөс - собственно тувинское название: хам - 'шаман / шаманский’; өөс (тоджинский диалект) - 'небольшая река, текущая в теснине’ (Татаринцев, 2008: 402).

История появления топонима: в русле горной реки растет шаманская лиственница (Ондар, 2007: 442). По другой версии - у реки, на узком проходе между горами, в старину шаманы совершали обряд поклонения духу горы перед тем, как отправить мужчин рода на сражение с врагом, чтобы защитить свой род, свою землю. С 1990-х годов, с возрождением шаманизма, данный обряд шаман проводит по просьбе людей, которые хотят добиться карьерного роста или преуспевать в жизни (Куулар и др., 2014: 66).

Хам-Сүyр - буквально «пик или вершина шамана», т. е. 'священная высокая гора': гора в Тоджинском районе (Ондар, 2007: 442). Хам-Сүүр - собственно тувинское название: хам - 'шаман / шаманский’; сүүр - 'сопка, пик; острый’ (Тувинско-русский словарь, 1968: 395). История появления топонима: метафорическое название - священная высокая гора (Ондар, 2007: 442).

Хам-Сыра Хaмсыра - буквально «шаман засохшее дерево», т. е. 'священное засохшее дерево': река и населенный пункт в Тоджинском районе; река, летняя стоянка в Бий-Хемском районе (там же: 442). Хам-Сыра - собственно тувинское название: хам - 'шаман / шаманский'; сыра - 1) засохшее дерево (хвойное); 2) жердь (Тувинско-русский словарь, 1968: 398). Собственно тувинский вторичный топоним: река именуется названием местности. История появления топонима: на территории населенного пункта есть засохшее дерево с причудливой формой, густо переплетенными ветвями в виде гнезда.

Таким образом, с компонентом хам 'шаман / шаманский’ зафиксировано 6 сложных по своему составу топонимов, которые являются названиями рек, местностей, горы и летних стоянок. Из них три названия являются вторичными, т. е. реки и низина именуются названиями летних стоянок и местности - Хам-Дыт (река и летняя стоянка), Хам-Дыттыг-Ой (местность и низина), Хам-Сыра (река и населенный пункт, летняя стоянка). Топоним Хам-Дыт зафиксирован и в Алтае, поэтому относится к странствующим топонимам.

\section{Топонимы, связанные с шаманскими обрядами}

Издавна освященное место считалось священным, поэтому тувинцы верили духам этих мест, поклонялись им, просили милости и благополучия (Куулар и др., 2014: 65). И в данном разделе мы анализируем топонимы в качестве первого или второго компонента которых выступают лексемы, связанные с шаманскими обрядами: дагыыр - 'освящать; совершать праздничный обряд' и саң ‘обряд окуривания’ (путем сжигания можжевельника).

Дагыыр-Tайга - буквально 'освященная тайга': тайга, хребет в Бай-Тайгинском районе (Ондар, 2007: 182). Дагыыр-Тайга - собственно тувинское название: дагыыр - 'освящать' (Тувинско-русский словарь, 1968: 142), тайга - 'тайга, таежный’ (там же: 403). История появления топонима: издавна на конусообразной вершине тайги шаманы совершали обряды освящения тайги (там же: 182).

Дагыыр-Тей - буквально 'освященный холм': гора в Барун-Хемчикском районе (там же: 182). Дагыыр-Тей - собственно тувинское название: дагыыр - 'освящать' (там же: 142), тей - 'холм, сопка' (там же: 410). История появления топонима: почитаемая небольшая гора (Ондар, 2007: 182); по другой версии - на небольшой горе вблизи населенного пункта Дон-Терезин, с возрождением шаманизма с 1990-х годов, стали совершать обряды освящения, поэтому в народе небольшую гору стали называть Дагыыьр-Тей (ПМА, 2018).

Сащ-Салыр - буквально 'совершить обряд окуривания' (там же: 368): гора в Бай-Тайгинском и ЧааХолском районах (там же: 348). Саң-Салыр - собственно тувинское название: саң - 'обряд окуривания можжевельника' (Толковый словарь ..., 2011: 641); салыр - 'класть, ставить', 'разжигать, подкладывать' (Тувинско-русский словарь, 1968: 366). История появления топонима: на горе местные жители во время обряда поклонения хозяину горы совершали обряд сащ салыр (Ондар, 2007: 348) - 'обряд окуривания (сжигания туркестанского можжевельника)' (Тувинско-русский словарь, 1968: 368). По другим источникам, обряд окуривания с подношениями проводят и молодые семьи, которые не могут иметь ребёнка, или во время празднования Шагаа - Нового года по восточному календарю (ПМА, 2016).

Саң-Хем - буквально 'река обряда окуривания (сжигания можжевельника)': река в Тоджинском районе (Ондар, 2007: 348). Саң-Хем - собственно тувинское название: саң - 'обряд окуривания мо- 
жжевельника'; хем - 'река’ (Тувинско-русский словарь, 1968: 473). История появления топонима: СањХем - правый приток реки Ак-Хем, где шаманы совершают обряд поклонения духу реки, окуривания с подношениями из белой еды (молочные продукты), чтобы местное население жило в здравии и достатке (Куулар и др., 2014: 65).

Чеди-Саң - буквально ‘семь обрядов окуривания (сжигания можжевельника)’ : гора на хребте Чээнек в Улуг-Хемском кожууне (Ондар, 2007:485; ПМА, 2003). Чеди-Саң- собственно тувинское название: чеди ‘семь’ (Тувинско-русский словарь, 1968: 524), саң - ‘обряд окуривания’. История появления топонима: священная гора, на которой постоянно совершают обряд поклонения хозяину горы, окуривания, т. е. сжигая можжевельник (Ондар, 2007: 485; ПМА, 2003). Топонимы с относительным количественным показателем ‘много, множество’ в тувинском языке могут быть выражены сакральным числительным чеди - 'семь', исключительное значение которого подтверждается фразеологизмами - чеди эртине ‘семь драгоценностей’; чеди дер - ‘семь потов’; чеди чүзүн мал - ‘скот из девяти мастей’ и т. д. (Кара-оол, 2019b: 696).

С древних времен тувинцы-шаманисты почитали духов рек (родников) и озер, гор, горных хребтов и перевалов, высокогорной тайги и жертвенных курганов (Куулар и др., 2014: 65-67). Поэтому рассмотренные нами топонимы, связанные с шаманскими обрядами, являются названиями гор, тайги и реки, на которых совершались обряды освящения и поклонения духам этих природных объектов.

\section{Топонимы с названиями шаманских атрибутов}

Во время шаманских обрядов используются различные атрибуты - дүңгүр - ‘бубен’, орба - ‘колотушка шаманского бубна', күзүңгү - ‘бронзовое зеркало шамана', кымчы - ‘кнут, плеть', бижек - 'нож’, хомус - 'хомус (музыкальный инструмент)', игил - 'игил (смычковый музыкальный инструмент)', ээрен - 'идол (шаманский)’ и т. д. (Куулар и др., 2014: 41-52). В собранных нами топонимах зафиксированы следующие наименования шаманских атрибутов:

Дүнгүр - ‘бубен (шаманский)' (Тувинско-русский словарь, 1968: 189): лесная местность на территории с. Ээрбек Кызылского района (ПМА, 1999). История появления топонима: во время грозы, ее звук эхом отзывается в лесной местности вблизи с. Ээрбек, как звук бубна во время камлания шамана, поэтому местность получила такое название (ПМА, 1999).

Дүнгүр - странствующий топоним. Тӥнӱр - ‘шаманский бубен’: река, гора, урочище, населенный пункт в Алтае (Молчанова, 1979: 320).

Чалама - 'разноцветные ленты (на шаманской одежде и на священных предметах)' (Тувинскорусский словарь, 1968: 513): местность, река, минеральный источник, гора, перевал в Улуг-Хемском, Кызылском, Тандинском, Дзун-Хемчикском районах (Ондар, 2007: 474). История появления топонима: как своеобразное жертвоприношение духу местности тувинцы развешивают разноцветные ленты на священных деревьях у истоков, на перевале, на приграничной зоне двух районов, поэтому эти местности называют Чалама (там же: 474). Также чалама развешивают на почитаемых местах в знак благодарности духам местности, в связи с рождением ребёнка (ПМА, 2012).

Ээреннниг-тей буквально - ‘холм или сопка, имеющая шаманский амулет' - гора в Чаа-Холском районе (Ондар, 2007: 537; ПМА, 2019). Ээренниг - собственно тувинское название: ээренниг - дериват ${ }^{1}$ ээрен 'идол (шаманский)' (Тувинско-русский словарь, 1968: 623); тей - ‘холм, сопка' (там же: 410). История появления топонима: на вершине горы шаман данной местности проводил обряд окуривания с использованием ээрена 'шаманского амулета’ (Ондар, 2007: 537).

Ээренниг-Хөл буквально - ‘озеро, имеющее шаманский амулет’ - озеро в Тоджинском районе (Ондар, 2007: 537). Ээренниг - собственно тувинское название: ээренниг дериват ээрен 'идол (шаманский)’ (Тувинско-русский словарь, 1968: 623); хөл - ‘озеро / озерный’ (там же: 489). История появления топонима: у озера шаман местности проводил обряд окуривания с использованием ээрена 'шаманского амулета’ (Ондар, 2007: 537).

Таким образом, три топонима, связанные с названиями шаманских атрибутов, являются названиями местности (Дүнгүр), горы (Ээренниг-Тей) и озера (Ээренниг-Хөл), за исключением вторичного топонима Чалама, который зафиксирован на территории многих районов Тувы и одновременно является названием местности, реки, минерального источника, горы, перевала - пример топонимической

\footnotetext{
${ }^{1}$ Дериват - производное слово (Розенталь, Теленкова, 2001: 102).
} 
метонимии. Дүңгұр - странствующий топоним, который в Алтае является вторичным топонимом, так как одновременно является названием нескольких географических объектов.

\section{Топонимы с названиями будийских строений}

Первые монастыри Эрзинский и Самагалтайский были построены на территории Тувы, примыкающей с Северо-Западной Монголией в 1772 и 1773 гг. Вслед за ними с начала XIX века стали строиться и другие храмы (Монгуш, 2001: 55-56). Это отразилось в названиях следующих топонимов:

Дуганды - буквально 'имеющая монастырь, храм': гора в Эрзинском районе (Ондар, 2007: 204). Дуганды - дериват дуган - 'храм, собор, церковь' (Тувинской-русский словарь, 1968: 180). История появления топонима: у подножия горы в 1772 г. был построен Эрзинский монастырь, который был одним из первых в Туве. Впоследствии он был перенесен на подножие горы Мандал: совет лам посчитал, что место для хүрээ было выбрано неудачно (Монгуш, 2001: 55-56), но гора так и осталась называться Дуганды, т. е. «гора с монастырем или храмом» (ПМА, 1999; Ондар, 2007: 204).

Дуганныг-Чарык - буквально 'ущелье с монастырем, храмом': местность в Дзун-Хемчикском районе (там же: 204). Дуганныг-Чарык - собственно тувинское название: дуганныг - 'имеющая монастырь', дериват дуган; чарык - 'ущелье'. История появления топонима: в местности вблизи современного поселка Хорум-Даг был монастырь, построенный в начале XX века (Монгуш, 2001: 56), его уничтожили в 30-е годы XX столетия - в годы культурной революции в Тувинской Народной Республике (ПМА, 2005).

Үстүү-Хүрээ - буквально 'верхняя церковь': местность в Дзун-Хемском районе (Ондар, 2008b: 194), на котором с 2008 по 2012 гг. восстановили один из крупнейших храмовых комплексов Тувы. YстүүХүрээ - собственно тувинское название: $ү с т ү ү-$ 'верхний’ (Тувинско-русский словарь, 1968: 453), $x \chi^{-}$ рээ - 'церковь, монастырь' (там же: 498). История появления топонима: под руководством хемчикского правителя Хайдыпа в 1905-1907 гг. по проекту тибетского ламы Кундана Ринпоче построили Yстүу-Чадаан хүрээзи - Верхнечаданское хурээ․ В 1937 г. он был разрушен. С тех пор местность, где остались высокие глинобитные стены разрушенного храма, местные жители стали называть YстүуХүрээ (ПМА, 1999). В 1999 г. Правительство России, признавая историческую и архитектурную ценность Устуу-Хурээ, приняло решение о его восстановлении. В том же году для привлечения внимания к храму и сбора средств на его восстановление по инициативе музыканта И. Дулуша был проведён первый Международный благотворительный фестиваль живой музыки и веры «Устуу-Хурээ», который с тех пор проводится ежегодно ${ }^{2}$. Восстановление храма началось в 2008 г. при поддержке С. К. Шойгу, российского министра по чрезвычайным ситуациям, и закончено в 2012 г. Церемония открытия УстууХурээ состоялась 23 июля 2012 г. ${ }^{3}$ В настоящее время Үстүү-Хүрээ - и название местности, и название храмового комплекса, куда приезжают паломники-буддисты.

Так, топонимы, связанные с названиями буддийских строений, являются названиями местностей и горы, где были возведены первые буддийские храмы.

\section{Топонимы с духовными званиями священнослужителей}

Священнослужители имеют определенные духовные и должностные звания или сан. И они отразились в названиях некоторых топонимов, называющих горы и местности вокруг этих гор.

Кегээн-Булак - буквально 'геген-долина (горная)': местность, минеральный источник вблизи населенного пункта Чадаан в Дзун-Хемчикском районе (Ондар, 2007: 250; 2008: 194). Кегээн-Булак - собственно тувинское название: кегээн - 'геген (духовное звание)' (Тувинско-русский словарь, 1968: 234), смотри монгольское гэгээн - 'светлый; святой, чистый; ясный', 'один из высших санов буддийского духовенства; титул перерожденца’ (Большой академический ..., 2001a: 477); булак - 'горная долина’, 'исток; ручей (в степи), родник’ (Тувинской-русский словарь, 1968: 121). История появления топони-

\footnotetext{
1 Лачугина А. Устуу-Хурээ - храм и фестиваль: подумать о своем месте в жизни // Центр Азии. 2012. № 28 (20-26 июля). С. 1.

${ }^{2}$ C 1999 г. до 2019 фестиваль проходил каждый год беспрерывно - 21 раз. В 2020 г. из-за пандемии COVID-19 фестиваль отменили, а в 2021 г. на брифинге об ограничениях на проведение майских праздников и фестиваля «Устуу-Хурээ» рекомендовано перенести на следующий год.

3 Лачугина А. Устуу-Хурээ - храм и фестиваль... С. 1.
} 
ма: по воспоминаниям одного из наших информаторов ${ }^{1}$, минеральный источник был освящен ламой с высшим духовным званием гегээн; по другой версии, гегээн-лама из Монголии, который побывал в этой местности, при отъезде наказал: «Срубите единственную лиственницу в ложбине, и на его месте забьет родник, и станет минеральным источником»². И действительно, когда срубили лиственницу, появился родничок, которому дали название Көгээн-Булак. Впоследствии родничок стал святым минеральным источником (ПМА, 2019), см. монгольское гегээн - ‘светлый, святой’ (Большой академический ..., 2001а: 477).

Лама-Даг - буквально 'лама гора': гора, местность вблизи поселка Баян-Кол Кызылского района (Ондар, 2007: 291). Лама-Даг - собственно тувинское название: лама - ‘лама, монах’ (Тувинскорусский словарь, 1968: 281); даг - ‘гора’ (там же: 140). История появления топонима: у подножия горы жил лама-монгол (ПМА, 2003), которого местные жители прозвали Чаштыг-Лама, буквально «лама с косичкой» (Ондар, 2007: 291).

Лама-Чуглур - буквально ‘лама скатывается’: гора и местность в Сут-Холском районе (там же: 291). Лама-Чуглур - собственно тувинское название: лама - ‘лама, монах’ чуглур - ‘катиться, скатываться’ (Тувинско-русский словарь, 1968: 545). История появления топонима: в начале XX века, во времена распространения буддизма в Сут-Хольском кожууне с горы свалился лама и с тех пор гору и местность вокруг этой горы стали называть Лама-Чуглур (Ондар, 2007: 291).

Хуурак-Хая - буквально 'послушник скала’: гора в Тес-Хемском районе (там же: 452). Хуурак-Хая собственно тувинское название: хуурак - 'послушник, ученик (в буддийских монастырях)' (Тувинскорусский словарь, 1968: 495; курсив источника. - Л. К.); хая - 'скала' (там же: 471). История появления топонима: на горе стоит скала, внешне напоминающая послушника, который сидя читает сутру религиозную книгу, содержащую проповеди Будды (ПМА, 2006; Ондар, 2007: 462).

Хуурак-Чайлыр - буквально 'послушник перевернулся': гористая местность вблизи с. Сесерлиг в Бий-Хемском районе (ПМА, 1999). Хуурак-Чайлыр - собственно тувинское название: хуурак - 'послушник, ученик'; чайлыр - ‘сваливаться, падать сверху’ (Тувинско-русский словарь, 1968: 512). История появления топонима: один из первых шоферов Тувы по имени Хуурак однажды на машине перевернулся на этом месте, поразив односельчан, так как он считался опытным шофером. И после этого случая местность стали называть Хуурак-Чайлыр (ПМА, 1999).

Топонимы, связанные с духовными званиями священнослужителей, в основном являются названиями гор, за исключением вторичного Кегээн-Булак, который зафиксирован как название местности и минерального источника.

\section{Топонимы, связанные с буддийскими понятиями}

Бумба - ‘банка (медицинская)’ (Тувинско-русский словарь, 1968: 122); гора, степь в Эрзинском районе (Ондар, 2007: 175). История появления топонима: известный в народе лама освящал местность и горы, в монгольском бумба 'посуда лам, в которую наливают аржаан для окропления' (там же: 175). По другой версии, в данной местности жил лама врачеватель, который лечил людей, используя медицинские банки (ПМА, 2019).

Бурган-Даи - буквально ‘божественный камень': местность в Сут-Холском районе (Ондар, 2007: 176). Бурган-Даш - собственно тувинское название: бурган - ‘бог; божество; бурхан, идол’ (Тувинскорусский словарь, 1968: 123), даш - ‘камень / каменный’ (там же: 149). История появления топонима: на местности есть большой камень с изображением бурханов со змеиной головой. На этом месте был храм (Ондар, 2007: 176), построенный в начале XX века (Монгуш, 2001: 56).

Бурганныг-Хая - буквально ‘божественная скала’: гора в Дзун-Хемчикском районе (Ондар, 2007 : 176). Бурганныг-Хая - собственно тувинское название: бурганныг дериват бурган - 'бог; божество; бурхан, идол’ (Тувинско-русский словарь, 1968: 123), хая - 'скала’ (там же: 471). История появления топонима: на горе есть скала с изображением Будды (Ондар, 2007: 176).

Канчыырлыг буквально - ‘имеющий буддийский отличительный знак’ - перевал в Дзун-Хемчикском районе (ПМА, 2019). Канчыыр - 1) ‘отличительный знак на крыше храма’; 2) ‘сборник буддийских

\footnotetext{
${ }^{1}$ Ооржак Билзеймаа Барын-ооловна, 45 лет, родилась в с. Баян-Тала Дзун-Хемчикского района.

${ }^{2}$ Донгак А. Кегээн-Булак // Шын. 2007. 10 ноября. С. 8.
} 
текстов из 108 томов, относящихся к разным областям знаний’ (Толковый словарь ... , 2011: 60), смотри монгольское слово ганжир - 'отличительный знак на крыше храма' (Большой академический ... , 2001a: 376). История появления топонима: на этом перевале побывал гегээн-лама, который предсказал появление минерального источника Кегээн-Булак на месте срубленной лиственницы, см. выше (ПМА, 2019).

Мандал - гора в Эрзинском районе (Ондар, 2007: 294): мандал 'возрождение, расцвет; подъем', ‘круглое блюдо с символическими изображениями, употребляемое при жертвоприношениях’ (Большой академический ..., 2001b: 319). История появления топонима: в 1772 г. Эрзинский монастырь был построен у горы Дуганды, но спустя некоторое время по решению совета лам его перенесли на подножие горы Мандал (Монгуш, 2001: 55). Совет посчитал, что выбрано неудачное место - якобы хозяйкой местности является женское божество, оказывающее разлагающее влияние на лам, которые перестали заучивать тексты буддийских книг, начали вести себя безнравственно и разнузданно (там же: 56). Совет лам, скорее всего, верил в то, что с переездом на новое место в монастыре возродится учение Будды.

\section{Топонимы, связанные с православием}

Появление русских в Урянхайском крае относится к 1838-1839 гг., в верховьях реки СыстыгХем основывались первые русские прииски (Родевич, 2007: 378). Край привлекал русских крестьян, золотоискателей, купцов своими природными богатствами и массой незанятых земель (там же: 354-363): с 1840 гг. началась меновая торговля между сойотами и казаками, стали появляться первые фактории русских купцов, велись работы по исследованию и изучению края, организовывались большие экспедиции (там же: 389-395), а с объявлением протектората царской России над Урянхаем в 1914 г., процесс переселения русских крестьян в Туву приобрел интенсивный характер, и вместе с ним начал складываться русский пласт топонимии Тувы. Первые деревни в центральных районах Тувы - Бий-Хемском, Каа-Хемком и Тандинском, в основном назывались именами, прозвищами первопоселенцев ${ }^{1}$ (Ондар, 2007: 268; см. также: Родевич, 2007: 474-511; Ховалыг, Даржа, 2020: 108), например, Германовка - село Сесерлиг в Бий-Хемском районе,

Даниловка - село Дерзиг-Аксы в Каа-Хемском районе,

Федоровка - село Кундустуг в Каа-Хемском районе,

Огневка - село Сайлыг в Чеди-Хольском районе,

Верхне-Никольский - село Бай-Хаак, центр Тандинского район и т. д.

До недавнего времени эти села имели два названия - тувинское и русское, но в настоящее время официальными являются тувинские, а русские названия помнят только старожилы сел.

Среди деревень есть несколько населенных пунктов, которые названы по мемориальному принципу, т. е. в память о православных святых, а также в честь религиозных праздников - Успенка, Знаменка, Ильинка.

Успенка - поселок в Тандинском районе (Ондар, 2007: 421).

Первыми жителями деревни Успенка были русские переселенцы. По воспоминаниям современных жителей села, она называлась по-разному - Нахаловка, Забегаловка (ПМА, 2018). По архивным данным, деревня была основана в 1918 г. русскими переселенцами в 55 км от Белоцарска (Кызыла) ${ }^{2}$ и названа Успенкой в честь религиозного праздника Успения Пресвятой Богородицы (15 августа): первые переселенцы заехали в Урянхайский край как раз в Успение (Ондар, 2011; ПМА, 2020).

Тувинское название местности, где первые русские переселенцы построили деревню Успенка Кара-Булущ, которое не используется как название деревни, но на территории других районов Тувы встречается как название местности, реки, урочища, стоянки (Ондар, 2007: 235).

Знаменка - первое название села Сарыг-Сеп, районного центра Каа-Хемского района (Ондар, 2008b: 268; ПМА, 2002). Основателями села были русские переселенцы-старообрядцы. Поселок основан

\footnotetext{
${ }^{1}$ Списки населенных пунктов Енисейской губернии и Урянхайского края. Часть 1. Списки, итоги и алфавитный указатель. Составлены по данным Всероссийской сельско-хозяйственной и городской переписи 1917 года и по другим исследованиям 1916-1919 гг. Красноярск: Типография Енисейского Губернского Союза кооперативов, 1921. 174 с. С. 146; Список поселков урянхайского края. Апрель 1918 г. (Национальный архив Республики Тыва, ф. 112, оп. 1, д. 84, л. 2).

${ }^{2}$ Списки населенных пунктов Енисейской губернии и Урянхайского края. Часть 1.... С. 148.
} 
в 1904 г. ${ }^{1}$ По воспоминаниям старожилов (ПМА, 2002), название одной из крупных деревень Тувы того времени связано с почитаемой иконой Знамения Пресвятой Богородицы, считавшейся чудотворной: знамение - 'знак, признак, примета; явление природы или чудо, для ознаменованья, доказательства, предвещанья чего’ (Даль, 2003: 610).

Ильинка - село в Каа-Хемском районе (Ондар, 2011: 112; ПМА, 2002). Семья первых переселенцев обосновалась на месте села в Ильин день - 2 августа (20 июля), в день памяти пророка Ильи, а также традиционного народного праздника народов, принявших православие (Ондар, 2011: 113). По архивным данным, деревню основали также в 1918 г. ${ }^{2}$

Таким образом, топонимов с духовно-религиозным значением православия немного. Это, скорее всего, объясняется тем, что, хотя в свое время произошло массовое переселение представителей православной культуры, местное население не было вовлечено в православие, как, например, в соседних регионах. В настоящее время из трех топонимов сохранились названия сел - Успенка и Ильинка в Тандинском районе. Есть предположение, что названия Нижне-Никольское и Верхне-Никольское тоже связаны с православием, но на основе материалов, собранных нами, они не подтвердились, поэтому требуют дальнейшего исследования.

\section{Этимологические и структурные особенности топонимов}

В этимологическом отношении в качестве первого или второго компонента сложных и простых топонимов с религиозным содержанием выступают:

1) общетюркские лексемы: хам - 'шаман / шаманский’ (Древнетюркский словарь, 1969: 413; Этимологический словарь ..., 1997: 240-241); чалама - 'разноцветные ленты (на шаманской одежде и на священных предметах)', 'флаг, знамя', 'священная лента, священный флажок (в шаманизме и бурганизме)’ (Рассадин, 1995: 83; Бутанаев, 1999: 208; Этимологический словарь ... , 1989: 99-100); дүнгүр - 'шаманский бубен', зафиксирован в тюркских языках Сибири (Татаринцев, 2002: 295); ээрен 'шаманский амулет' (Рассадин, 1971: 184);

Вторые компоненты, выраженные общетюркскими лексемами: адыр - 'приток' или 'развилина', см. айыр - 'развилина', 'ответвление' (Севортян, 1974: 114-116; Татаринцев, 2000: 61); дыт - 'лиственница’ (Древнетюркский словарь, 1969: 569; Татаринцев, 2002: 322-325); тей - 'холм, сопка', см. см. tej - 'холм', 'темя’ (Сравнительно-историческая грамматика ..., 2001: 201); салыр см. сал- - 'класть, положить', 'ставить, поставить' и под. (Этимологический словарь ..., 2003: 173-177; Татаринцев, 2018: 51); хем 'река', см. кем - 'река (Древнетюркский словарь, 1969: 297); чеди - 'семь' см. йеди 'семь' (Этимологический словарь ... , 1989: 167); үстүу - 'верхний’, см. үст - 'верх’ (Севортян, 1974: 638); булак - 'горная долина', 'исток; ручей (в степи)' (Севортян, 1978: 257); даг - 'гора’ (Севортян, 1980: 117; Татаринцев, 2002: 35); чуглур - 'катиться, скатываться’, см. јиу- - 'уронить, опрокинуть' (Рассадин, 1971: 198); хая - 'скала', см. gaja - 'скала' (Древнетюркский словарь, 1969: 406); ой - 'низина, лощина' (Татаринцев, 2008: 271), сүүр - 'сопка, пик; острый’ (Татаринцев, 2018: 151), сыра 'засохшее дерево; жердь’ (там же: 163-165); өөс (тодж.) - ‘небольшая река, текущая в теснине’, этимология слова отсутствует (Татаринцев, 2008: 402).

2) монгольские заимствования: дагыыр дагы- - 'освящать; совершать религиозный обряд' (там же: 40), см. монг. тахил - 'обряд жертвоприношения’ (Большой академический ..., 2001с: 203); саң 'обряд окуривания можжевельника', монголизм, см. сан(2) - 'курение ладаном' (там же: 84); мандал 'возрождение, расцвет; подъем', 'круглое блюдо с символическими изображениями, употребляемое при жертвоприношениях’ (Большой академический ..., 2001b: 319); хүрээ(н) - 'крупный монастырь' (Большой академический ..., 2002: 193); хуурак см. монгольский хувраг - 'ученик ламы', 'послушник дацана, духовное лицо, монах’ (там же: 156), бумба - 'кувшин, ваза, сосуд; урна’ (Большой академический ..., 2001а: 287); бурган - бурхан - ‘бог, божество; будда, бурхан' (там же: 291).

3) тибетские заимствования посредством монгольского, как, например, Дуганды дериват дуган 'храм, собор, церковь', см. монг. дуган - 'небольшой монастырь, храм' (Большой академический ... , 2001b: 66); кегээн (уст. рел.) - 'геген (духовное звание)' см. монгольское гэгээн - 'светлый; чистый; ясный', 'один из высших санов буддийского духовенства; титул перерожденца' (Большой академический ..., 2001а: 477); лама - ‘лама, буддийский монах’, см. монгольский лам (Большой академичес-

${ }^{1}$ Списки населенных пунктов Енисейской губернии и Урянхайского края. Часть 1.... С. 146.

${ }^{2}$ Там же. С. 148. 
кий ..., 2001b: 300); канчыырлыг - 'имеющий отличительный знак на крыше храма', см. монгольское ганжир - 'отличительный знак на крыше храма: фигура в форме вазы’ (там же: 376);

4) русские лексические заимствования: Успенка - успение, церк. Успение богородицы, древне-русское усъпение - 'засыпание, сон; смерть, кончина; церковный праздник' (Фасмер, 2004b: 172); Знаменка - старо-славянское знаменье - 'признак'- древне-русское знамя - 'знак, печать' (Фасмер, 2004a: 100); Ильинка - Илья, имя собственное, древне-русское (там же: 128).

В структурном отношении значительную часть топонимов с конфессиональной лексикой составляют собственно тувинские сложные слова, образованные из двух основ (22): Хам-Дыт, Хам-Сыра, Дагыығ-Тей, Чеди-Саң, Ээрен-Тайга, Үстүү-Хүрээ и т. д. И несколько простых топонимов с производной: Дүнгүр, Канчыырлыг, Дуганды; Успенка, Знаменка, Ильинка и непроизводной основой - Чалама, Мандал, Бумба.

\section{Заключение}

Таким образом, в географических названиях Тувы выделены топонимы, выражающие религиознокультовые представления тувинцев и первых русских переселенцев. Если тувинские топонимы, связанные с шаманизмом и буддизмом указывают на обрядовую деятельность, ритуальные атрибуты, статус служителей вероисповедания, разновидности строений, то топонимы, связанные с православием, образованы по принципу мемориальности - в память о православных святых, а также в честь религиозных праздников.

В структурном и этимологическом отношениях значительную часть топонимов с религиозно-духовным содержанием составляют собственно тувинские сложные слова. В качестве первого компонента сложных топонимов или простых топонимов выступают конфессиональная общетюркская лексика, лексические заимствования из монгольского, из тибетского языка посредством монгольского, а также из русского языка, а вторые компоненты сложных слов выражены общетюркскими словами. Наличие в составе топонимов с духовно-религиозным содержанием следующих формантов - гидронимических (хем - 'река', хөл - 'озеро'), фитонимических (дыт - 'лиственница', сыра - 'засохшее дерево или жердь'), оронимических (тайга - 'тайга', тей - 'холм', сүүр - 'вершина', ой - 'низина') - указывают на то, что они увязывались с природно-географическими особенностями Тувы.

Населенные пункты, названные в память о православных святых, а также в честь православных религиозных праздников, зафиксированы в Каа-Хемском и Тандинском районах, в которые интенсивно расселялись первые русские переселенцы.

Среди топонимов с конфессиональной лексикой зафиксированы два странствующих тюркских названия - Хам-Дыт и Дүнгүр. Ареалом распространения данных топонимов являются Тува и Алтай.

В целом надо отметить, что в системе топонимов Тувы собственные имена с духовно-религиозным содержанием, хотя образуют достаточно интересную группу, весьма раритетны, по сравнению с другими лексико-семантическими группами, как растительный или животный мир Тувы, цветообозначения, природно-климатические особенности региона и т. д. Но, тем не менее, можно заключить, что шаманизм, буддизм и православие оставили своеобразный след в топонимической системе Тувы, подтверждая уникальность региональной географической среды, без которой невозможно создать целостную картину топонимического пространства Центральной Азии.

\section{СПИСОК ЛИТЕРАТУРЫ}

Бавуу-Сюрюн, М. В., Куулар, Ч. К. (2005) Структура топонимов монгольского происхождения на территории Тувы // Тыва дылдың лексиказынга факультативтер [Факультативы по лексике тувинского языка] / науч. ред. Е. Б. Салзынмаа. Кызыл : Аныяк. 116 с. С. 111-115.

Бавуу-Сюрюн, М. В. (2018) Топонимы как маркеры диалектов и говоров тувинского языка //Новые исследования Тувы. № 3. С. 18-32. DOI: https://doi.org/10.25178/nit.2018.3.2

Большой академический монгольско-русский словарь (2001a) / отв. ред. Г. Ц. Пюрбеев. М. : ACADEMIA. Т. I. А-Г. $520 \mathrm{c}$.

Большой академический монгольско-русский словарь (2001b) / отв. ред. Г. Ц. Пюрбеев. М. : ACADEMIA. Т. II. Д-О. $514 \mathrm{c}$. 
Большой академический монгольско-русский словарь (2001с) / отв. ред. Г. Ц. Пюрбеев. М. : ACADEMIA. T. III. $\Theta-Ф .440$ c.

Большой академический монгольско-русский словарь (2002) / отв. ред. Г. Ц. Пюрбеев. М. : ACADEMIA. T. IV. X-Я. 510 c.

Бутанаев, В. Я. (1999) Хакасско-русский историко-этнографический словарь. Абакан : УПП «Хакасия». 240 с.

Даль, В. И. (2003) Толковый словарь живого великорусского языка : в 4 т. М. : ОЛМА-ПРЕСС ; ОАО ПФ «Красный пролетарий». Т. 1. А-3. 640 с.

Древнетюркский словарь (1969) / ред. В. М. Наделяев, Д. М. Насилов, Э. Р. Тенишев, А. М. Щербак. Л. : Наука. 676 с.

Дулов, В. И. (1956) Социально-экономическая история Тувы. XIX - начало XX в. / отв. ред. С. А. Токарев. М. : Изд-во Академии наук СССР. 609 с.

Кара-оол, Л. С. (2018) Лексические особенности топонимов Овюрского района Тувы // Новые исследования Тувы. № 3. С. 162-189. DOI: https://doi.org/10.25178/nit.2018.3.11

Кара-оол, Л. С. (2019а) Лексика родильных обрядов в топонимах Тувы // Мир науки, культуры, образования. Вып. 3 (76). С. 368-369.

Кара-оол, Л. С. (2019b) Числительные в топонимах Тувы // Oriental Studies. № 4. С. 691-706. DOI: https://doi. org/10.22162/2619-0990-2019-44-4-691-706

Кара-оол, Л. С. (2020) Зоокомпоненты в тувинской топонимии // Мир науки, культуры, образования. № 5 (84). С. 280-284.

Кенин-Лопсан, М. Б. (1987) Обрядовая практика и фольклор тувинского шаманизма. Конец XIX - начало XX в. Новосибирск : Наука. 168 с.

Куулар, Х., Куулар, Ө., Куулар, Д.-Д., Куулар, Л.-Д. (2014) Хам болгаш делегей [Шаман и мир]. Кызыл : Типография КЦО «Аныяк». 132 с.

Молчанова, О. Т. (1979) Топонимический словарь Алтая / под ред. А. Т. Тыбыковой. Горно-Алтайск : ГорноАлтайское отделение Алтайского книжного издательства. 398 с.

Монгуш, М. В. (1992) Ламаизм в Туве. Историко-этнографическое исследование. Кызыл : Тувинское книжное издательство. 144 с.

Монгуш, М. В. (2001) История буддизма в Туве (вторая половина VI - конец XX в.). Новосибирск : Наука. 200 с.

Ондар, Б. К. (2007) Топонимический словарь Тувы. 2-е изд., перераб. Кызыл : ТувКИ. 552 с.

Ондар, Б. К. (2008а) Тувинская топонимика: проблемы, поиски, решения. Проблемы преподавания русского языка в вузе и в школе. Кызыл : РИО ТувГУ. 233 с.

Ондар, Б. К. (2008b) Тувинская топонимия. Сопоставительный анализ топонимии Тувы с топонимией Южной Сибири и других тюркоязычных территорий. Кызыл : Тувинское книжное издательство. 304 с.

Ондар, Б. К. (2011) Русская топонимия Тувы. Кызыл : РИО ТувГУ. 168 с.

Рассадин, В. И. (1971) Фонетика и лексика тофаларского языка / отв. редактор Ц. Б. Цыдендамбаев. Улан-Удэ : Бурятское книжное издательство. 252 с.

Рассадин, В. И. (1995) Тофаларско-русский словарь. Русско-тофаларский словарь / отв. ред. И. Д. Бураев. Иркутск : Восточно-Сибирское книжное издательство. 288 с.

Родевич, В. М. (2007) Очерк Урянхайского края // Урянхай. Тыва дептер. Антология научной и просветительской мысли о древней тувинской земле и ее насельниках, об Урянхае - Танну-Туве, урянхайцах - тувинцах, о древностях Тувы : в 7 т. / сост. С. К. Шойгу. М. : Слово / Slovo. Т. 3: Урянхайский край. Тувинско-русские отношения (начало XVII - начало XX вв.). 608 с. С. 342-542.

Розенталь, Д. Э., Теленкова, М. А. (2001) Словарь-справочник лингвистических терминов. М. : ООО «Издательство “Астрель” ; ООО «Издательство “АСТ”». 624 с.

Сат, Ш. Ч. (1969) Заметки по топонимии Тувы // Материалы конференции «Этногенез народов Северной Азии» / отв. ред. Е. И. Убрятова. Вып. 1. Новосибирск : б/и. 247 с. С. 232-234.

Севортян, Э. В. (1974) Этимологический словарь тюркских языков: общетюркские и межтюркские основы на гласные / ред. Р. М. Залесковская. М. : Наука. 768 с.

Севортян, Э. В. (1978) Этимологический словарь тюркских языков: общетюркские и межтюркские основы на букву “Б” / отв. ред. Н. З. Гаджиева. М. : Наука. 352 с. 
Севортян, Э. В. (1980) Этимологический словарь тюркских языков: общетюркские и межтюркские основы на буквы “В”, “Г”, “Д” / отв. ред. Н. З. Гаджиева. М. : Наука. 390 с.

Сравнительно-историческая грамматика тюркских языков. Лексика (2001) / отв. ред. Э. Р. Тенишев. М. : Наука. 822 c.

Сувандии, Н. Д. (2013) Современное состояние изучения ономастики тувинского языка // Мир науки, культуры, образования. Вып. 6 (43). С. 362-364.

Сувандии, Н. Д. (2018) Вклад Бичен Кыргысовны Ондар в развитие топонимики Тувы // Новые исследования Тувы. № 3. C. 4-17. DOI: https://doi.org/10.25178/nit.2018.3.1

Сувандии, Н. Д. (2019) Топонимы-цветообозначения в тувинском языке // Новые исследования Тувы. № 4. C. 195-206. DOI: https://doi.org/10.25178/nit.2019.4.16

Сувандии, Н. Д., Кара-оол, Л. С., Болармаа, Б. (2019) Барыын Моолдуң Цэнгэл сумузунуң топонимнери [Топонимы сумона Цэнгэл Западной Монголии]. Кызыл : КИТувГУ. 86 с.

Сувандии, Н. Д., Кара-оол, Л. С. (2020) Словарь странствующей ономастики тувинского языка. Кызыл : Редакция ТувГУ. 64 с.

Татаринцев, Б. И. (1973) Об особенностях топонимии Северо-Восточной Тувы // Происхождение аборигенов Сибири и их языков : мат. всесоюз. конф. 14-16 июня 1973 г. / ред. коллегия: Э. Г. Беккер [и др.]. Томск : Изд-во Томского университета. 235 с. С. $142-144$.

Татаринцев, Б. И. (1977а) Местные географические термины Северо-Восточной Тувы // Советская тюркология / гл. ред. М. Ш. Ширалиев. Баку : Тип-я им. 26 бакинских комиссаров. Вып. 5. 112 с. С. 18-26.

Татаринцев, Б. И. (1977b) О топонимии бассейна р. Каа-Хем // Тувинский язык и литература в послеоктябрьский период / ред. коллегия: Д. А. Монгуш (отв. ред.) [и др.]. Кызыл : Тип-я управления по делам издательств, полиграфии и книжной торговли Совета Министров Тув. АССР. 192 с. С. 88-98.

Татаринцев, Б. И. (1993) О некоторых древних топонимах тюркского происхождения на территории Тувы // Вопросы тувинского языкознания / ред. Д. А. Монгуш, Б. И. Татаринцев. Кызыл : Новости Тувы. 128 с. С. $105-113$.

Татаринцев, Б. И. (2000) Этимологический словарь тувинского языка. Новосибирск : Наука. Т. І. А-Б. 341 с.

Татаринцев, Б. И. (2002) Этимологический словарь тувинского языка. Новосибирск : Наука. Т. II. Д-Й. 388 с.

Татаринцев, Б. И. (2004) Этимологический словарь тувинского языка. Новосибирск : Наука. Т. III. К-Л. 440 с.

Татаринцев, Б. И. (2008) Этимологический словарь тувинского языка. Новосибирск : Наука. Т. IV. M-П. 442 с.

Татаринцев, Б. И. (2018) Этимологический словарь тувинского языка. Новосибирск : Наука. Т. V. С. 180 с.

Татаринцева, М. П. (2006) Старообрядцы в Туве: историко-этнографический очерк. Новосибирск : Наука. 216 с.

Толковый словарь тувинского языка (2011) : в 2 т. / ред. Д. А. Монгуш. Новосибирск : Наука. Т. II: К-С. 798 с.

Тувинско-русский словарь (1968) : 22000 слов / ред. Э. Р. Тенишев. М. : Советская энциклопедия. 648 с.

Фасмер, М. (2004а) Этимологический словарь русского языка : в 4 т. / пер. с нем. и доп. О. Н. Трубачева. 4-е изд., стер. М. : ООО «Издательство “Астрель”»; ООО «Издательство “АСТ”». Т. 2. (Е-Муж). 671 с.

Фасмер, М. (2004b) Этимологический словарь русского языка : в 4 т. / пер. с нем. доп. О. Н. Трубачева. 4-е изд., стер. М. : ООО «Издательство “Астрель” ; ООО «Издательство “АСТ”». Т. 4. (Т-Ящур). 860 с.

Ховалыг, С. С., Даржа, У. А. (2020) Архивные документы по именованиям муниципальных образований Тувы (1759-2005 гг.) // Новые исследования Тувы. № 2. С. 103-119. DOI: https://doi.org/10.25178/nit.2020.2.7

Этимологический словарь тюркских языков: Общетюркские и межтюркские основы на буквы “К” ( Г) и “Қ” ( “К” “К”) (1997) / отв. ред. Г. Ф. Благова. М. : Языки русской культуры. Вып. 1. 368 с.

Этимологический словарь тюркских языков: Общетюркские и межтюркские основы на буквы “Ж” и “Ж”, “Й” (1989) / отв. ред. Л. С. Левитская. М. : Наука. 294 с.

Этимологический словарь тюркских языков: общетюркские и межтюркские лексические основы на буквы “Л”, “М”, “Н”, “П”, “С” (2003) / отв. ред. А. В. Дыбо. М. : Восточная литература. 446 с.

Дата поступления: 14.04.2021 2.

\section{REFERENCES}

Bavuu-Surun, M. V. and Kuular, Ch. K. (2005) Struktura toponimov mongol'skogo proiskhozhdeniia na territorii Tuvy [Structure of toponyms of Mongolian origin in the territory of Tuva]. In: Tyva dyldy leksikazynga fakul'tativter [Electives in the vocabulary of the Tuvan language] / ed. by E. B. Salzynmaa. Kyzyl, Anyiak. 116 p. Pp. 111-115. (In Russ.). 
Bavuu-Surun, M. V. (2018) Toponimy kak markery dialektov i govorov tuvinskogo iazyka [Place names as markers of the dialects and sub-dialects of Tuvan language]. New Research of Tuva, no. 3, pp. 18-32. (In Russ.). DOI: https://doi. org/10.25178/nit.2018.3.2

Bol'shoi akademicheskii mongol'sko-russkii slovar' [The large academic Mongolian-Russian dictionary] (2001a) : in 4 vols. / executive editor G. Ts. Piurbeev. Moscow, Academia. Vol. 1. 520 p. (In Russ.).

Bol'shoi akademicheskii mongol'sko-russkii slovar' [The large academic Mongolian-Russian dictionary] (2001b) : in 4 vols. / executive editor G. Ts. Piurbeev. Moscow, Academia. Vol. 2. 536 p. (In Russ.).

Bol'shoi akademicheskii mongol'sko-russkii slovar' [The large academic Mongolian-Russian dictionary] (2001c) : in 4 vols. / executive editor G. Ts. Piurbeev. Moscow, Academia. Vol. 3. 440 p. (In Russ.).

Bol'shoi akademicheskii mongol'sko-russkii slovar' [The large academic Mongolian-Russian dictionary] (2002) : in 4 vols. / executive editor G. Ts. Piurbeev. Moscow, Academia. Vol. 4. 532 p. (In Russ.).

Butanaev, V. (1999) Khakassko-russkii istoriko-etnograficheskii slovar' [A Khakas-Russian historical and ethnographic dictionary]. Abakan, UPP Hakasiya. 240 p. (In Russ.).

Dal, V. I. (2003) Tolkovyi slovar' zhivogo velikorusskogo iazyka [Explanatory dictionary of the living great Russian language] : in 4 vols. Moscow, OLMA-PRESS ; Krasnyi proletarii. Vol. 1. 640 p. (In Russ.).

Drevnetiurkskii slovar' [An old Turkic dictionary] (1969) / ed. by V. M. Nadeliaev, D. M. Nasilov, E. R. Tenishev and A. M. Shcherbak. Leningrad, Nauka. 679 p. (In Russ.).

Dulov, V. I. (1956) Sotsial'no-ekonomicheskaia istoriia Tuvy. XIX - nachalo XX v. [The socio-economic history of Tuva. 19th - early 20th centuries]. Moscow, Publishing House of the Academy of Sciences of the USSR. 608 p. (In Russ.).

Kara-ool, L. S. (2018) Leksicheskie osobennosti toponimov Oviurskogo raiona Tuvy [Lexical features of microtoponyms of Ovyur rayon of Tuva]. New Research of Tuva, no. 3, pp. 162-189. (In Russ.). DOI: https://doi.org/10.25178/nit.2018.3.11

Kara-ool, L. S. (2019a) Leksika rodil'nykh obriadov v toponimakh Tuvy [Vocabulary of maternity rites in toponyms of Tuva]. Mir nauki, kul'tury, obrazovaniia, no. 3, pp. 368-369. (In Russ.).

Kara-ool, L. S. (2019b) Chislitel'nye v toponimakh Tuvy [Numerals in toponyms of Tuva]. Oriental Studies, no. 4, pp. 691-706. (In Russ.). DOI: https://doi.org/10.22162/2619-0990-2019-44-4-691-706

Kara-ool, L. S. (2020) Zookomponenty v tuvinskoi toponimii [Animal-related names in Tuvinian toponymy]. Mir nauki, kul'tury, obrazovaniia, no. 5 (84), pp. 280-284. (In Russ.).

Kenin-Lopsan, M. B. (1987) Obriadovaia praktika i fol'klor tuvinskogo shamanstva. Konets XIX - nachalo XX v. [Ritual practice and folklore of Tuvinian shamanism. Late 19th - early 20th century]. Novosibirsk, Nauka. 165 p. (In Russ.).

Kuular, Kh., Kuular, Ö., Kuular, D.-D. and Kuular, L.-D. (2014) Kham bolgash delegei [Shaman and the world]. Kyzyl, Printing House of the Kyzyl Educational Center “Anyiak”. 132 p. (In Russ.).

Molchanova, O. T. (1979) Toponimicheskii slovar' Altaia [A toponymic dictionary of Altai] / ed. by A. T. Tybykova. GornoAltaisk, Gorno-Altaisk Branch of the Altai Book Publishing House. 398 p. (In Russ.).

Mongush, M. V. (1992) Lamaizm v Tuve : istoriko-etnograficheskoe issledovanie [Lamaism in Tuva: A historical and ethnographic study]. Kyzyl, Tuvan Book Publisher. 144 p. (In Russ.).

Mongush, M. V. (2001) Istoriia buddizma v Tuve (vtoraia polovina VI - konets XX v.) [The history of Buddhism in Tuva (Latter half of the 6th - late 20th cc.)]. Novosibirsk, Nauka. 200 p. (In Russ.).

Ondar, B. K. (2007) Toponimicheskii slovar' Tuvy [A toponymic dictionary of Tuva]. 2nd ed. Kyzyl, Tuvan Book Publisher. 550 p. (In Russ.).

Ondar, B. K. (2008a) Tuvinskaia toponimika: problemy, poiski, resheniia [Tuvan toponyms: Problems, investigations, solutions]. Kyzyl, Editorial and Publishing Unit at Tuvan State University. 233 p. (In Russ.).

Ondar, B. K. (2008b) Tuvinskaia toponimiia. Sopostavitel'nyi analiz toponimii Tuvy s toponimami Iuzhnoi Sibiri i drugikh tiurkoiazychnykh territorii [Tuvan toponyms. A comparative analysis of toponyms of Tuva with those of southern Siberia and other Turkic-speaking territories]. Kyzyl, Tuvan Book Publisher. 296 p. (In Russ.).

Ondar, B. K. (2011) Russkaia toponimiia Tuvy [Russian placenames in Tuva]. Kyzyl, Editorial and Publishing Unit at Tuvan State University. 168 p. (In Russ.).

Rassadin, V. I. (1971) Fonetika i leksika tofalarskogo iazyka [Phonetics and lexics of the Tofalar language]. Ulan-Ude, Buryat Book Publisher 252 p. (In Russ.).

Rassadin, V. I. (1995) Tofalarsko-russkii slovar'. Russko-tofalarskii slovar' [Tofalar-Russian dictionary. Russian-Tofalar Dictionary] / ed. by I. D. Buraev. Irkutsk, East Siberian Book Publishing House. 288 p. (In Russ.). 
Rodevich, V. M. (2007) Ocherk Uriankhaiskogo kraia [An outline of the Uriankhai region]. In: Uriankhai. Tyva depter [Uriankhai. Tyva depter] : in 7 vols. / comp. by S. K. Shoigu. Moscow, Slovo. Vol. 3: Uriankhaiskii krai. Tuvinsko-russkie otnosheniia (nachalo XVII - nachalo XX vv.) [Uriankhai region. Tuvan-Russian relations (early 17th - early 20th centuries)]. 608 p. Pp. 342-542. (In Russ.).

Rosenthal, D. E. and Telenkova, M. A. (2001) Slovar'-spravochnik lingvisticheskikh terminov [Dictionary-reference of linguistic terms]. Moscow, Astrel ; AST. 624 p. (In Russ.).

Sat, Sh. Ch. (1969) Zametki po toponimii Tuvy [Notes on the toponymy of Tuva]. In: Materialy konferentsii «Etnogenez narodov Severnoi Azii» [Proceedings of the conference "Ethnogenesis of the Peoples of North Asia"] / ed. by E. I. Ubriatova. Vol. 1. Novosibirsk, s. n. 247 p. Pp. 232-234. (In Russ.).

Sevortian, E. V. (1974) Etimologicheskii slovar' tiurkskikh iazykov: obshchetiurkskie i mezhtiurkskie osnovy na glasnye [An etymological dictionary of Turkic languages: Common Turkic and inter-Turkic vowel bases] / ed. by R. M. Zaleskovskaia. Moscow, Nauka. 768 p. (In Russ.).

Sevortian E. V. (1978) Etimologicheskii slovar' tiurkskikh iazykov: obshchetiurkskie i mezhtiurkskie osnovy na bukvu "B” [An etymological dictionary of Turkic languages: Common Turkic and inter-Turkic bases with the letter "B”]/ ed. by N. Z. Gadzhieva. Moscow, Nauka. 352 p. (In Russ.).

Sevortian E. V. (1980) Etimologicheskii slovar' tiurkskikh iazykov: obshchetiurkskie i mezhtiurkskie osnovy na bukvy "V”, “G”, “ $D$ ” [An etymological dictionary of Turkic languages: Common Turkic and inter-Turkic bases with the letters “ $V$ ”, “ $G$ ”, “ $D$ ”] ed. by N. Z. Gadzhieva. Moscow, Nauka. 390 p. (In Russ.).

Sravnitel' no-istoricheskaia grammatika tiurkskikh iazykov. Leksika [A comparative historical grammar of Turkic languages. Vocabulary] (2001) / ed. by E. R. Tenishev. Moscow, Nauka. 800 p. (In Russ.).

Suvandii, N. D. (2013) Sovremennoe sostoianie izucheniia onomastiki tuviskogo iazyka [Current state of studying onomastics of the Tuvan language]. Mir nauki, kul'tury, obrazovaniia, no. 6, pp. 362-364. (In Russ.).

Suvandii, N. D. (2018) Vklad Bichen Kyrgysovny Ondar v razvitie toponimiki Tuvy [Bichen Kyrgyzovna Ondar and her contribution to the study of the toponymy of Tuva]. New Research of Tuva, no. 3, pp. 4-17. (In Russ.). DOI: https://doi. org/10.25178/nit.2018.3.1

Suvandii, N. D. (2019) Toponimy-tsvetooboznacheniia v tuvinskom iazyke [Place names of color designation in Tuvan language]. New Research of Tuva, no. 4, pp. 195-206. (In Russ.). DOI: https://doi.org/10.25178/nit.2019.4.16

Suvandii, N. D., Kara-ool, L. S. and Bolarmaa, B. (2019) Baryyn Moolduß Tsengel sumuzunuњ toponimneri [Toponyms of Sumon Tsengel in Western Mongolia]. Kyzyl, Tuvan State University. 86 p. (In Russ.).

Suvandii, N. D. and Kara-ool, L. S. (2020) Slovar' stranstvuiushchei onomastiki tuvinskogo iazyka [A dictionary of wandering onomastics of the Tuvan language]. Kyzyl, Tuvan State University. 64 p. (In Russ.).

Tatarintsev, B. I. (1973) Ob osobennostiakh toponimii severo-vostochnoi Tuvy [About the peculiarities of toponyms of North-Eastern Tuva]. In: Proiskhozhdenie aborigenov Sibiri i ikh iazykov [The origin of aboriginal peoples of Siberia and their languages] : Proceedings of All-Union conference, June 14-16, 1973. Tomsk, Tomsk University Publ. 236 p. Pp. $142-144$. (In Russ.).

Tatarintsev, B. I. (1977a) Mestnye geograficheskie terminy severo-vostochnoi Tuvy [Local geographical terms of NorthEastern Tuva]. In: Sovetskaia tiurkologiia [Soviet Turkology]. Vol. 5 / ed. by M. Sh. Shiraliev. Baku, 26 Baku Commissars Printing House. 112 p. Pp. 18-26. (In Russ.).

Tatarintsev, B. I. (1977b) O toponimii basseina r. Kaa-Khem [On the toponyms of the river Kaa-Khem]. In: Tuvinskii iazyk i literatura $v$ posleoktiabr'skii period [Tuvan language and literature in the post-October period] / ed. by D. A. Mongush. Kyzyl, Printing House of the Department for Publishing, Printing and Book Trade of the Council of Ministers of the Tuvan ASSR. 192 p. Pp. 88-98. (In Russ.).

Tatarintsev, B. I. (1993) O nekotorykh drevnikh toponimakh tiurkskogo proiskhozhdeniia na territorii Tuvy [On some ancient toponyms of Turkic origin in the territory of Tuva]. In: Voprosy tuvinskogo iazykoznaniia [Questions of Tuvan linguistics] / ed. by D. A. Mongush and B. I. Tatarintsev. Kyzyl, Novosti Tuvy. 128 p. Pp. 105-113. (In Russ.).

Tatarintsev, B. I. (2000) Etimologicheskii slovar' tuvinskogo iazyka [An etymological dictionary of the Tuvan language]. Novosibirsk, Nauka. Vol. I. 339 p. (In Russ.).

Tatarintsev, B. I. (2002) Etimologicheskii slovar' tuvinskogo iazyka [An etymological dictionary of the Tuvan language]. Novosibirsk, Nauka. Vol. II. 388 p. (In Russ.).

Tatarintsev, B. I. (2004) Etimologicheskii slovar' tuvinskogo yazyka [An etymological dictionary of the Tuvan language]. Novosibirsk, Nauka. Vol. III. 440 p. (In Russ.). 
Tatarintsev, B. I. (2008) Etimologicheskii slovar' tuvinskogo iazyka [An etymological dictionary of the Tuvan language]. Novosibirsk, Nauka. Vol. IV. 442 p. (In Russ.).

Tatarintsev, B. I. (2018) Etimologicheskii slovar' tuvinskogo iazyka [An etymological dictionary of the Tuvan language]. Novosibirsk, Nauka. Vol. V. 180 p. (In Russ.).

Tatarintseva, M. P. (2006) Staroobriadtsy v Tuve: istoriko-etnograficheskii ocherk [Old believers in Tuva: A historical and ethnographic essay]. Novosibirsk, Nauka. 216 p. (In Russ.).

Tolkovyi slovar' tuvinskogo iazyka [An explanatory dictionary of the Tuvan language] (2011) / ed. by D. A. Mongush. Novosibirsk, Nauka. Vol. II. 798 p. (In Russ. and Tuv.).

Tuvinsko-russkii slovar' [A Tuvan-Russian dictionary] (1968) : c. 22000 words / ed. by E. R. Tenishev. Moscow, Sovetskaia entsiklopediia. 465 p. (In Russ. and Tuv.).

Fasmer, M. (2004a) Etimologicheskii slovar' russkogo iazyka [An etymological dictionary of the Russian language] : in 4 vols. / transl. from Germ. and ed. by O. N. Trubacheva. 4nd ed. Moscow, Astrel ; AST. Vol. 2. 671 p. (In Russ.).

Fasmer, M. (2004b) Etimologicheskii slovar' russkogo iazyka [An etymological dictionary of the Russian language] : in 4 vols. / transl. from Germ. and ed. by O. N. Trubacheva. 4nd ed. Moscow, Astrel ; AST. Vol. 4. 860 p. (In Russ.).

Khovalyg, S. S. and Darzha, U. A. (2020) Arkhivnye dokumenty po imenovaniiam munitsipal'nykh obrazovanii Tuvy (1759-2005 gg.) [Archival documents on placenames of Tuvan municipalities (1759-2005)]. New Research of Tuva, no. 2 , pp. 103-119. (In Russ.). DOI: https://doi.org/10.25178/nit.2020.2.7

Etimologicheskii slovar' tiurkskikh iazykov: Obshchetiurkskie i mezhtiurkskie leksicheskie osnovy na bukvy «K», «K» [An etymological dictionary of Turkic languages: Common Turkic and inter-Turkic lexical bases with the letters "K”, “K”] (1997) / comp. by L. S. Levitskaia et al. Moscow, Iazyki russkoi kul'tury. Vol. V. 368 p. (In Russ.).

Etimologicheskii slovar' tiurkskikh iazykov: Obshchetiurkskie i mezhtiurkskie osnovy na bukvy "Zh" $i$ "Zh", "I" [An etymological dictionary of Turkic languages: Common Turkic and inter-Turkic bases with the letters "Zh" and "Zh", "I"] (1989) / ed. by L. S. Levitskaia. Moscow, Nauka. 294 p. (In Russ.).

Etimologicheskii slovar' tiurkskikh iazykov: obshchetiurkskie i mezhtiurkskie leksicheskie osnovy na bukvy "L", " $M$ ”, " $N$ ", “ $P$ ”, "S" [An etymological dictionary of Turkic languages: Common Turkic and inter-Turkic lexical bases with the letters " $L$ ”, " $M$ ", " $N$ ", “P”, “S”] (2003) / ed. by A. V. Dybo. Moscow, Vostochnaia literatura. 446 p. (In Russ.).

Submission date: 14.04 .2021$. 